\title{
Effect of different maturation diets on reproductive performance of the broodstock of purple mangrove crab, Scylla tranquebarica
}

\author{
Thien Fui Yin and Annita Yong Seok Kian* \\ Borneo Marine Research Institute, Universiti Malaysia Sabah, 88400 Kota Kinabalu, Sabah, Malaysia \\ ${ }^{*}$ Corresponding author: annitay@ums.edu.my
}

\begin{abstract}
The present study was aimed at evaluating the reproductive performance of the broodstock of purple mangrove crab (Scylla tranquebarica) fed natural food and formulated diets supplemented with astaxanthin and/or DHA. Formulated diets were supplemented with $500 \mathrm{mg} \mathrm{kg}^{-1}$ of astaxanthin (FA), $10 \mathrm{~g} \mathrm{~kg}^{-1}$ of DHA (FD) and both astaxanthin and DHA (FA+D). Diet without astaxanthin and DHA (FCon) and natural food (NF) consisted of forage fish (Valamugil sp.), shrimp (Penaeid sp.) and mangrove clam (Polymesoda sp.) to serve as control. Female broodstock of initial body weight $129.07 \pm 17.03 \mathrm{~g}$ were stocked in HDPE tank and cultured under recirculating water system. Broodstock maturation was monitored until spawning. Reproductive performance of female and condition of the larvae were also evaluated. After 50 weeks, broodstock fed FA+D diet showed better maturation percentage, spawning rate, gonadosomatic index, oocytes diameter, molting, molt death syndrome and survival rate than FCon group $(\mathrm{P}<0.05)$. Maturation performance of broodstock fed FA and FD diets was almost similar $(\mathrm{P}>0.05)$ to the FA+D group but diet FD resulted in better performance than FA. Broodstock fed FA+D diet had the highest hatching rate, number of larvae produced and significantly higher zoea II survival compared to FCon and NF groups $(\mathrm{P}<0.05)$. No significant difference was observed in hatching rate and zoea II survival rate when broodstock were fed FA+D, FA and FD diets. This study indicated that DHA as well as astaxanthin improved the reproductive performance of the mangrove crab, and the use of both DHA and astaxanthin further enhanced the maturation performance.
\end{abstract}

Keywords: Mangrove crab, Maturation, Natural food, Formulated diet

\section{Introduction}

Appropriate maturation diet is crucial for promoting the reproductive performance of the mangrove crab broodstock (Millamena et al., 2000). Natural food items such as forage fish, mussel and marine polychaete worms have been found to induce maturation in mangrove crab (Quinitio et al., 2001). However, the quality of natural food varies seasonally and can influence the process of maturation. Natural food deteriorates fast and requires proper storage, without which its nutritional value is diminished. These items also impair the water quality if left in the tank for extended periods (Millamena et al., 2000). For all these and environmental reasons, formulated diets provide a better alternative to the natural food. Studies have shown that formulated diets offered reliable supply of known nutritional ingredients to induce maturation in crustacean broodstock (Xu etal., 1994; Pangantihon-Kuhlmann et al., 1998; Cavalli et al., 1999; Wen et al., 2002). Nutritional supplements such as astaxanthin and highly unsaturated fatty acids (HUFA) have been reported to enhance maturation-supporting role of the diet for crustaceans (Pangantihon-Kuhlmann et al., 1998; Djunaidah et al., 2003; Alava et al., 2007; Huang et al., 2008).

In previous studies, elevation of docosahexaenoic acid (DHA) in the maturation diet by incorporating fish oil improved the reproductive performance of the crustacean broodstock (Millamena, 1989; Alava et al., 1993; Xu et al., 1994; Cavalli et al., 1999; Wen et al., 2002; Djunaidah et al.,
2003; Wu et al., 2007; Paibukilchakul et al., 2008). Inclusion of DHA $10.6 \mathrm{~g} \mathrm{~kg}^{-1}$ in the green mangrove crab broodstock (Scylla paramamosain) maturation diet significantly increased the egg hatching rate compared to the broodstock fed control diet of natural food comprising forage fish, squid and shrimp ( $\mathrm{P}<0.05)$ (Djunaidah et al., 2003). Broodstock of Chinese mitten crab (Eriocheir sinensis) fed diet supplemented with HUFA $25 \mathrm{~g} \mathrm{~kg}^{-1}$ and containing DHA amounting to $13.0 \%$ of quantity of total fatty acids in the diet resulted in significantly higher $(\mathrm{P}<0.05)$ gonadosomatic index (GSI) and egg production than the broodstock fed diet that contained HUFA $3 \mathrm{~g} \mathrm{~kg}^{-1}$ and DHA $1.45 \%$ of total fatty acids (Wu et al., 2007). In another study, Chinese mitten crab broodstock fed diet supplemented with anchovy oil in a proportion of $60 \mathrm{~g} \mathrm{~kg}^{-1}$ comprising DHA to the tune of $5.7 \%$ of total fatty acids in the diet also resulted in significantly higher GSI and hatching rate than control diet without anchovy oil $(\mathrm{P}<0.05)$ (Wen et al., 2002). Broodstock of black tiger prawn (Penaeus monodon) fed diet supplemented with fish oil at the rate of $80 \mathrm{~g} \mathrm{~kg}^{-1}$ which contained DHA constituting $20.6 \%$ of total fatty acids in the diet also showed significantly greater $(P<0.05)$ number of eggs and spermatozoa than broodstock fed fish oil at the rate of $30 \mathrm{~g}$ $\mathrm{kg}^{-1}$ containing DHA as much as $14.9 \%$ of total fatty acids (Paibulkichakul et al., 2008). In other species, Xu et al. (1994) reported significant increase in the number eggs, nauplii and hatching rate in the broodstock of Chinese prawn (P. chinensis) fed with anchovy oil $100 \mathrm{~g} \mathrm{~kg}^{-1}$ containing DHA 
amounting to $5.7 \%$ of total fatty acids in the diet than the specimens not provided anchovy oil. Research on fresh water prawn (Macrobrachium rosenbergii) conducted by Cavalli et al. (1999) showed that the broodstock fed diet comprising a high concentration of $n-3$ HUFA (DHA 12.76\% of total fatty acids) in the diet showed significantly higher fecundity, GSI and hatching rate than broodstock fed diet with low level inclusion of n-3 HUFA (DHA 5.42\% of total fatty acids). Earlier studies have emphasized the important role played by DHA in the reproductive performance of the Chinese mitten crab and shrimp broodstock. However, there is little information on the use of DHA in the case of purple mangrove crab broodstock.

Astaxanthin is the major carotenoid in shrimp and crab (Tanaka et al., 1976; Okada et al., 1994; Sachindra et al., 2005) without which these animals cannot synthesize de vono carotenoid. They need to obtain it from diet (FelixValenzuela et al., 2000). Huang et al. (2008) reported that supplementation of maturation diet of the tiger prawn with astaxanthin at the rate of $50 \mathrm{mg} \mathrm{kg}^{-1}$ resulted in significantly higher spawning rate than broodstock fed control diet without astaxanthin $(\mathrm{P}<0.05)$. However, when supplementation of astaxanthin was increased to $100 \mathrm{mg} \mathrm{kg}-$ 1 , the ovarian development and spawning performance of the tiger prawn broodstock were improved and significantly higher GSI was noted than in broodstock fed control diet without astaxanthin $(\mathrm{P}<0.05)$ (Pangantihon-Kuhlmann et al., 1998). Furthermore, Paibukilchakul et al. (2008) demonstrated that further inclusion of astaxanthin to a level of $500 \mathrm{mg} \mathrm{kg}^{-1}$ in the maturation diet of the tiger prawn broodstock resulted in greater number of eggs and spermatozoa $(\mathrm{P}<0.05)$. There is, of course, need for further investigations on the most effective quantity. Requirements of such nutrients increase during maturation and biological systems help in their accumulation in the ovary for the preparation of spawning. HUFA is one of those nutrients that is highly accumulated in the ovary of crustaceans (Paibukilchakul et al., 2008). These nutrients need to be preserved and protected from peroxidation in the ovary. Astaxanthin is a strong antioxidant (Miki, 1991). It can serve as an inhibitor of lipid peroxidation due to its strong quenching effect against singlet oxygen and free radicals (Miki, 1991). Like HUFA, astaxanthin is also accumulated in the crustacean ovary to play this function (Dall et al., 1995). The use of astaxanthin in maturation of shrimp and fish is well documented (Watanabe et al., 1984; Guillou et al., 1989; Verakunpiriya et al., 1997; Sawanboonchun et al., 2008; Tizkar et al., 2016). However, there is a lack of information on the use of the combination of DHA and astaxanthin in the maturation performance of purple mangrove crab broodstock.

In recent years, the demand of mangrove crabs has increased. Hatchery seed production is needed to support the growing farming industry since the supply from the wild is declining. The seed collected from the natural environment for grow-out is not always of good quality and is also not adequate. Broodstock maturation diet can play a vital role in production of good quality seed. Although Scylla

tranquebarica (Figure 1) is the dominant species in Sabah, Malaysia (Sharif et al., 2016) but limited information is available on its maturation diet. This study was undertaken with the aim of improving the maturation and fertility of the crab by supplementing its diet with DHA and astaxanthin.

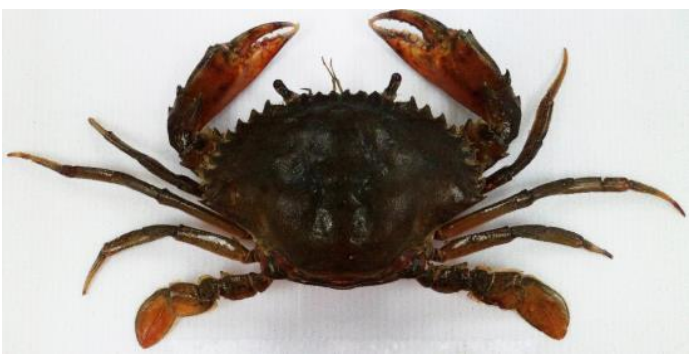

Figure 1. Female purple mangrove crab broodstock (S. tranquebarica)

\section{Materials and Methods}

\section{Test specimen of crab}

The experiment was conducted at the shrimp hatchery of Borneo Marine Research Institute, Universiti Malaysia Sabah. Specimens of the crab broodstock used in this study were purchased from local fishermen at Kota Marudu (6 ${ }^{\circ} 29^{\prime} 13.79 "$ $\left.\mathrm{N}, 116^{\circ} 44^{\prime} 5.99 " \mathrm{E}\right)$. The crabs were disinfected with $100 \mathrm{ppm}$ of formaldehyde (37\%) for one hour before stocking into the culture tanks for conditioning as suggested by Millamena et al. (2000). During conditioning, the crabs were fed with natural food and gradually weaned to formulated diet for 7 days.

Table 1. Formulation and proximate analysis of experimental diets (g/100g dry weight basis)

\begin{tabular}{|c|c|c|c|c|}
\hline \multirow{2}{*}{ Ingredients (g/100g) } & \multicolumn{4}{|c|}{ Dietary treatments } \\
\hline & $F A$ & $F D$ & $F A+D$ & FCon \\
\hline Danish fishmeal $^{1}$ & 47.88 & 47.88 & 47.88 & 47.88 \\
\hline Squid meal2 ${ }^{2}$ & 12.05 & 12.05 & 12.05 & 12.05 \\
\hline Fish oil & 4.37 & 3.12 & 3.12 & 4.37 \\
\hline Vitamin mix & 3.00 & 3.00 & 3.00 & 3.00 \\
\hline Mineral mix & 4.00 & 4.00 & 4.00 & 4.00 \\
\hline Cholesterol & 1.00 & 1.00 & 1.00 & 1.00 \\
\hline Calcium phosphate & 3.00 & 3.00 & 3.00 & 3.00 \\
\hline Soy lecithin & 3.00 & 3.00 & 3.00 & 3.00 \\
\hline $\begin{array}{l}\text { Carboxymethylcellulose } \\
\text { sodium }\end{array}$ & 4.00 & 4.00 & 4.00 & 4.00 \\
\hline Alpha-starch & 17.21 & 17.71 & 17.21 & 17.71 \\
\hline Astaxanthin ${ }^{3}$ & 0.50 & - & 0.50 & - \\
\hline DHA oil 4 & - & 1.25 & 1.25 & - \\
\hline Proximate analysis (\%) & $F A$ & $F D$ & $F A+D$ & FCon \\
\hline Crude protein & $\begin{array}{c}47.0 \pm \\
0.4\end{array}$ & $\begin{array}{c}46.5 \pm \\
0.6\end{array}$ & $\begin{array}{c}47.0 \pm \\
0.4\end{array}$ & $\begin{array}{c}46.8 \pm \\
0.5\end{array}$ \\
\hline Crude lipid & $\begin{array}{c}12.9 \pm \\
0.3\end{array}$ & $\begin{array}{c}12.4 \pm \\
0.1\end{array}$ & $\begin{array}{c}13.0 \pm \\
0.1\end{array}$ & $\begin{array}{c}12.3 \pm \\
0.2\end{array}$ \\
\hline Moisture & $\begin{array}{c}7.9 \pm \\
0.2\end{array}$ & $\begin{array}{c}9.3 \pm \\
0.2\end{array}$ & $\begin{array}{c}7.0 \pm \\
0.3\end{array}$ & $\begin{array}{c}9.1 \pm \\
0.1\end{array}$ \\
\hline Ash & $\begin{array}{c}14.3 \pm \\
0.1\end{array}$ & $\begin{array}{c}14.3 \pm \\
0.3\end{array}$ & $\begin{array}{c}14.5 \pm \\
0.2\end{array}$ & $\begin{array}{c}14.1 \pm \\
0.1\end{array}$ \\
\hline $\mathrm{NFE}^{5}$ & $\begin{array}{c}25.8 \pm \\
0.4\end{array}$ & $\begin{array}{c}26.8 \pm \\
0.4\end{array}$ & $\begin{array}{c}25.5 \pm \\
0.6\end{array}$ & $\begin{array}{c}26.8 \pm \\
0.2\end{array}$ \\
\hline $\begin{array}{l}{ }^{1} \text { Danish fishmeal (g/100g dry weight): } \\
{ }^{2} \text { Squid (g/100g dry weight): } 83.00 \mathrm{~g} \text { cr } \\
{ }^{3} \text { Carophyll pink from DSM, Switzerlan } \\
{ }^{4} \text { DHA oil from Bizen Chemical Co. Ltd, } \\
{ }^{5} \mathrm{NFE} \text { (nitrogen-free extract) }=100-(\mathrm{p}\end{array}$ & $\begin{array}{l}\mathrm{g} \text { crude pro } \\
\text { rotein, } 6.62 \mathrm{~g} \\
\text { tained } 10 \% \\
80 \% \text { purity } \\
\text { + lipid + as }\end{array}$ & $\begin{array}{l}\mathrm{n}, 12.19 \mathrm{~g} \mathrm{cr} \\
\text { ude lipid } \\
\text { ynthetic ast }\end{array}$ & lipid & \\
\hline
\end{tabular}




\section{Experimental diets}

Broodstock were given four formulated diets that contained $46 \%$ of crude protein and $12 \%$ of crude lipid. These were modified from the maturation diet for the broodstock of giant mangrove crab (S. serrata) (Millamena et al., 1997). Formulated diet was supplemented with $500 \mathrm{mg} \mathrm{kg}^{-1}$ of astaxanthin (FA), $10 \mathrm{~g} \mathrm{~kg}^{-1}$ of DHA (FD), and both astaxanthin and DHA $(F A+D)$. Diet without any of the astaxanthin and DHA (FCon) and natural food (NF) comprising forage fish (Valamugil sp.), shrimp (Penaeid sp.) and mangrove clam (Polymesoda sp.) were given as control. Synthetic astaxanthin (10\% purity) from DSM (Switzerland) and DHA oil (80\% purity) from Bizen Chemical Co. Ltd (Japan) were used in this study.

Table 2. Proximate analysis of the natural food (dry weight basis)

\begin{tabular}{lccc}
\hline $\begin{array}{l}\text { Proximate } \\
\text { analysis (\%) }\end{array}$ & $\begin{array}{c}\text { Forage fish } \\
\text { (Valamugil sp.) }\end{array}$ & $\begin{array}{c}\text { Shrimp } \\
\text { (Penaeid sp.) }\end{array}$ & $\begin{array}{c}\text { Mangrove clam } \\
\text { (Polymesoda sp.) }\end{array}$ \\
\hline Crude protein & $18.6 \pm 0.1$ & $17.4 \pm 0.1$ & $11.8 \pm 0.0$ \\
Crude lipid & $1.2 \pm 0.1$ & $0.8 \pm 0.0$ & $1.6 \pm 0.1$ \\
Moisture & $76.6 \pm 0.4$ & $76.0 \pm 0.5$ & $78.3 \pm 1.0$ \\
Ash & $9.1 \pm 0.1$ & $15.1 \pm 0.1$ & $11.4 \pm 0.4$ \\
\hline
\end{tabular}

All these formulated diets contained the same basal composition except astaxanthin and DHA. The dried ingredients were weighed and mixed thoroughly. This was followed by addition of oil and $40 \%$ of water to make it into a moist mixture. Astaxanthin was dissolved in water before adding the other dry ingredients. Then the moist dough was passed through a $6 \mathrm{~mm}$ meat mincer extruder and shaped into noodle-like feed. These moist feeds were dried in the oven for 24 hours at $45^{\circ} \mathrm{C}$. The dried feeds were kept in zip locked bag and stored in the freezer $-20{ }^{\circ} \mathrm{C}$ until used. Diets were subjected to proximate biochemical analysis which included crude protein, lipid, ash and moisture (AOAC, 1990) before commencement of the feeding trials. The crude protein for the formulated diets was in the range of $46.5-47.0 \%$, crude lipid was $12.3-13.0 \%$ and moisture $7.0-9.3 \%$ (Table 1 ). The natural food items comprised crude protein (11.8 $18.6 \%$ ), whereas the lipid and moisture varied from 0.8 $1.6 \%$ and $76.0-78.3 \%$, respectively (Table 2 ).

\section{Rearing protocol}

In the present study, pre-puberty female crab with abdominal flap shape that was intermediate between V- and U-shapes (Islam et al., 2010) was selected for the experiment. Female crabs of initial body weight $129.07 \pm 17.03 \mathrm{~g}$ were distributed into rectangular HDPE tank $(180 \mathrm{~cm} \times 120 \mathrm{~cm} \times 50 \mathrm{~cm})$ in a recirculating system with stocking density of 10 crabs (3 males +7 females) in each tank. Each culture tank was provided with 12 pieces of PVC pipe $(10 \mathrm{~cm}$ of diameter and $20 \mathrm{~cm}$ in length) as shelter. A tray of $0.2 \mathrm{~m}^{2}$ filled with $\sim 10$ $\mathrm{cm}$ depth of sand was placed in each culture tank as a substrate for the female to spawn.

The tanks were filled with filtered and disinfected sea water. Disinfection was carried out with $20 \mathrm{ppm}$ of commercial grade chlorine (65\%) for 24 hours, followed by dechlorination of water with $5 \mathrm{ppm}$ of sodium thiosulfate for 24 hours (Shelley et al., 2011). Temperature, salinity, $\mathrm{pH}$ and dissolved oxygen in the water were monitored daily. Nitrate and nitrite were checked weekly by using test kit (Hach) and UV spectrophotometer (Hach DR5000, Germany). Salinity was maintained in the range of $19.09-21.76 \mathrm{ppt}$, temperature $26.16-29.11^{\circ} \mathrm{C}$, dissolved oxygen $5.85-6.79$ ppm, pH $7.42-8.06$, nitrite concentration $0.0008-0.0108$ $\mathrm{mg} \mathrm{L}^{-1}$ and nitrate concentration $1.079-1.089 \mathrm{mg} \mathrm{L}^{-1}$.

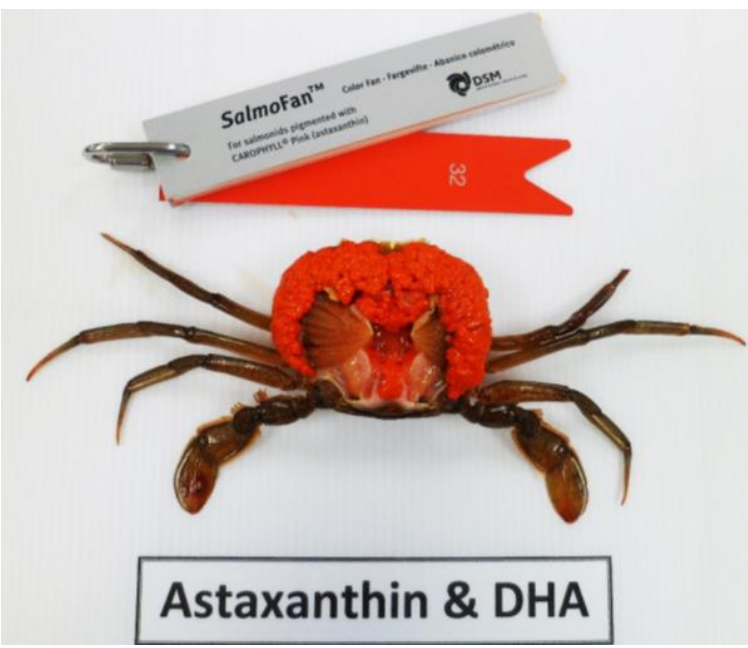

Figure 2. Mature female was sacrificed and ovarian tissue was sampled for analysis and gonadosomatic index (GSI) estimation

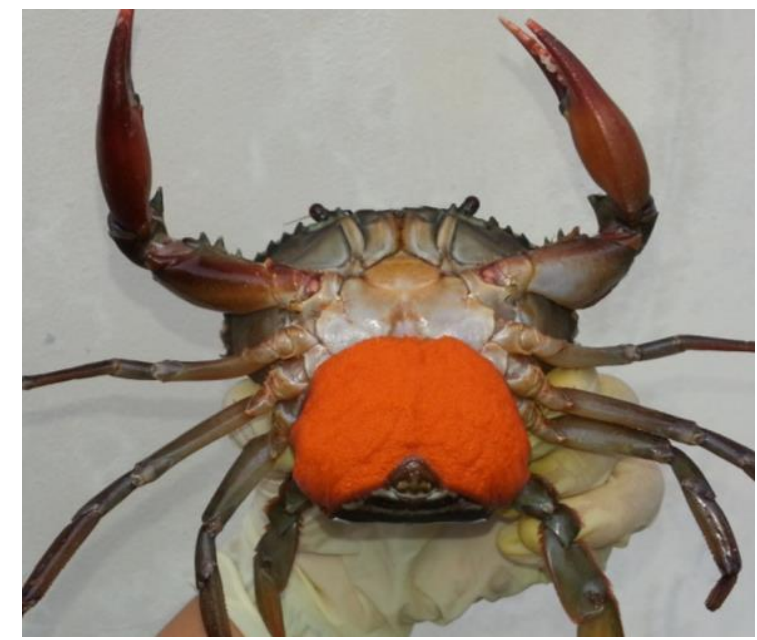

Figure 3. Berried female of purple mangrove crab broodstock

Broodstock was given diets according to the feeding protocol explained above at $5 \%$ of total biomass twice a day (0900 and $1730 \mathrm{~h}$ ) until molting and mating. Each diet was fed to triplicate groups of broodstock. Any uneaten food was siphoned off twice a day before feeding time. Dead specimen, if any, was removed from the tank. The female was continuously fed the experimental diets and monitored daily until spawning occurred. Ovarian maturation was determined by visual observation of the gonads through the gap between the first abdominal segment and the carapace (Djunaidah et al., 2003). Mature female was sacrificed and ovarian tissue was sampled for analysis and estimation of gonadosomatic index (GSI) (Figure 2). A portion of the ovarian tissue was preserved for histological observations that included measurement of the diameter of at least 20 oocytes with an image analyzer (Carl Zeiss Axioplan 2 
Imaging 310080, Germany) (Quinitio et al., 2007). Molt Death Syndrome (MDS) in which the crab broodstock died during molting was recorded.

After spawning, berried female specimens (Figure 3) were isolated individually into a $100 \mathrm{~L}$ incubation tank for hatching to observe the larval quality. After hatching, the number of larvae was estimated (Djunaidah et al., 2003). The larval rearing protocol of zoea I was slightly modified according to Quinitio et al. (2001). The zoea I was transferred into $100 \mathrm{~L}$ cubical fiber glass tanks with stocking density of 30 individuals $\mathrm{L}^{-1}$. This was done in triplicate sets. The larvae were fed with rotifer (Brachionus sp.) at the rate of 15 individuals $\mathrm{ml}^{-1}$ (Quinitio et al., 2001). Water was maintained at 30 - 32 ppt salinity, 26.75 to $29.48{ }^{\circ} \mathrm{C}$ temperature, 5.33 $5.81 \mathrm{ppm}$ dissolved oxygen and the $\mathrm{pH}$ was in the range of 8.26 - 8.50. All the tanks were subjected to natural photoperiod of about 12 hours light. Rearing was terminated when all zoea I metamorphosed into zoea II. The number of zoea II survived in the culture tank was determined. The whole feeding trial was conducted for 50 weeks.

\section{Data analysis}

The mean percentage of maturation, spawning, GSI, oocytes diameter, molting, MDS, survival rate, hatching rate, fecundity, total number of larvae produced and survival of zoea II were determined at the end of the feeding trial. The percentage data was transformed prior to statistical analysis. One-way factorial analysis of variance (ANOVA) and Tukey's multiple comparison tests were used to determine the differences among the data obtained at $\mathrm{P}<0.05$.

\section{Results}

The results revealed that the crab broodstock fed FA+D diet showed the best performance among all the groups in terms of significantly higher maturation percentage (56.02 \pm $6.26 \%)$, spawning rate $(43.98 \pm 6.26 \%)$, GSI $(18.75 \pm 2.97 \%)$ and oocytes diameter $(266.44 \pm 18.14 \mu \mathrm{m})$ compared to FCon treatment $(\mathrm{P}<0.05)$ (Table 3$) . \mathrm{FA}+\mathrm{D}$ diet also resulted in significantly higher molting rate $(66.67 \pm 15.28 \%)$, survival rate $(50.00 \pm 10.00 \%)$ and significantly lower MDS (6.67 \pm $5.77 \%$ ) than FCon treatment $(\mathrm{P}<0.05)$ (Table 4). Broodstock fed FCon diet showed the lowest maturation rate, spawning rate, GSI, oocytes diameter and survival rate. Besides, lowest molting rate $(19.30 \pm 6.08 \%)$ and highest MDS (47.37 \pm $10.53 \%$ ) were observed in FCon-treated specimens. Broodstock fed either FA or FD diet had almost similar maturation performance with $\mathrm{FA}+\mathrm{D}$ group, with no significant difference $(\mathrm{P}>0.05)$. However, the broodstock fed FD performed better than broodstock provided FA.

The broodstock fed FA+D, FA and FD diets showed comparable maturation or somewhat better performance visa-vis NF group except GSI and oocytes diameter where NF produced significantly lower $(\mathrm{P}<0.05)$ result. Broodstock fed $\mathrm{NF}$ and FCon diets showed almost similar maturation performance except oocytes diameter, molting and survival rate. The NF treatment yielded better $(\mathrm{P}<0.05)$ results than the FCon group.
Table 3. Crab broodstock maturation, spawning, GSI and oocytes diameter under different dietary treatments

\begin{tabular}{|c|c|c|c|c|}
\hline Treatment & $\begin{array}{c}\text { Maturation } \\
\text { (\%) }\end{array}$ & $\begin{array}{c}\text { Spawning } \\
(\%)\end{array}$ & $\begin{array}{l}\text { GSI } \\
\text { (\%) }\end{array}$ & $\begin{array}{c}\text { Oocytes } \\
\text { diameter }(\mu \mathrm{m})\end{array}$ \\
\hline FA & $\begin{array}{l}24.1 \pm \\
12.6^{\mathrm{ab}}\end{array}$ & $\begin{array}{l}12.0 \pm \\
12.5^{\mathrm{ab}}\end{array}$ & $17.9 \pm 1.5^{b}$ & $261.3 \pm 16.6^{c}$ \\
\hline FD & $40.3 \pm 8.7 b$ & $28.2 \pm 8.1^{b}$ & $18.7 \pm 0.4^{b}$ & $265.3 \pm 14.5^{c}$ \\
\hline $\mathrm{FA}+\mathrm{D}$ & $56.0 \pm 6.3^{b}$ & $44.0 \pm 6.3^{b}$ & $18.8 \pm 3.0^{\mathrm{b}}$ & $266.4 \pm 18.1^{c}$ \\
\hline FCon & $7.6 \pm 6.6^{a}$ & $1.9 \pm 3.2^{\mathrm{a}}$ & $12.3 \pm 0.6^{\mathrm{a}}$ & $194.5 \pm 13.7 \mathrm{a}$ \\
\hline $\mathrm{NF}$ & $28.2 \pm 8.1^{\mathrm{ab}}$ & $\begin{array}{c}16.2 \pm \\
7.7 \mathrm{ab}\end{array}$ & $13.4 \pm 1.7 \mathrm{a}$ & $242.6 \pm 23.4^{b}$ \\
\hline
\end{tabular}

Number of female broodstock, $n=25$.
Superscripts within each column denote significant difference $(P<0.05)$.

Maturation rate $(\%)=$ Number of females matured $/$ Total number of female specimens $\times 100$ Spawning rate $(\%)=$ Number of females spawned $/$ Total number of female specimens $\times 100$ (Sui et al., 2011)

GSI (\%) = Gonad wet weight (g) / Broodstock body wet weight (g) × 100 (Wu et al., 2007)

Table 4. Crab broodstock molting rate, molt death syndrome (MDS) and survival rate under different dietary treatments

\begin{tabular}{|c|c|c|c|}
\hline Treatment & $\begin{array}{c}\text { Molting } \\
\text { (\%) }\end{array}$ & $\begin{array}{l}\text { MDS } \\
\text { (\%) }\end{array}$ & $\begin{array}{c}\text { Survival } \\
(\%)\end{array}$ \\
\hline FA & $40.0 \pm 0.0^{b}$ & $23.3 \pm 11.6^{\mathrm{ab}}$ & $30.0 \pm 10.0^{a b}$ \\
\hline FD & $46.7 \pm 5.8^{\mathrm{bc}}$ & $16.7 \pm 5.8^{\mathrm{ab}}$ & $43.3 \pm 5.8^{b}$ \\
\hline $\mathrm{FA}+\mathrm{D}$ & $66.7 \pm 15.3^{c}$ & $6.7 \pm 5.8^{a}$ & $50.0 \pm 10.0^{b}$ \\
\hline FCon & $19.3 \pm 6.1^{\mathrm{a}}$ & $47.4 \pm 10.5^{b}$ & $12.3 \pm 6.1^{a}$ \\
\hline NF & $43.3 \pm 5.8^{b}$ & $36.7 \pm 5.8^{b}$ & $33.3 \pm 5.8^{b}$ \\
\hline \multicolumn{4}{|c|}{$\begin{array}{l}\text { Number of female broodstock, } \mathrm{n}=25 \text {. } \\
\text { Superscripts within each column denote significant difference }(\mathrm{P}<0.05) \text {. } \\
\text { Molting rate }(\%)=\text { Number of broodstock molted / Total number of broodstock } \times 100 \\
\text { MDS }(\%)=\text { Number of broodstock dead during molting / } \\
\text { Total number of broodstock } \times 100 \\
\text { Survival rate }(\%)=\text { Number of broodstock survived / Total number of broodstock } \times 100 \text { (Oniam et } \\
\text { al., 2012) }\end{array}$} \\
\hline
\end{tabular}

Table 5. Larval hatching rate, fecundity, total no. larvae produced and survival of zoea II

\begin{tabular}{lcccc}
\hline Treatment & $\begin{array}{c}\text { Hatching Fecundity } \\
(\mathbf{\% )}\end{array}$ & $\begin{array}{c}\text { Total } \\
\left(\mathbf{\times 1 0}^{3}\right)\end{array}$ & $\begin{array}{c}\text { Survival of } \\
\text { Larvae }\left(\times \mathbf{1 0}^{3}\right)\end{array}$ & zoea II (\%) \\
\hline FA & 80.81 & 1598 & 1292 & $80.60 \pm 5.15^{\mathrm{b}}$ \\
FD & 98.66 & 705 & 696 & $84.81 \pm 4.63^{\mathrm{b}}$ \\
FA+D & 98.82 & 1549 & 1531 & $90.66 \pm 6.30^{\mathrm{b}}$ \\
FCon & 28.30 & 1283 & 363 & $53.42 \pm 7.84^{\mathrm{a}}$ \\
NF & 64.63 & 1348 & 871 & $61.55 \pm 11.58^{\mathrm{a}}$ \\
\hline N
\end{tabular}

Superscripts within each column denote significant differences $(\mathrm{P}<0.05)$.

Sutching rate $(\%)=$ Number of larvae hatched out $/$ Fecundity $\times 100$ (Oniam et al., 2012)

Fecundity $=$ Number of newly hatched larvae + total number of unhatched eggs (Oniam et al., 2012)

Survival rate (\%) = Number of crab larvae left / Number of initial crab larvae (Oniam et al., 2012)

Broodstock fed FA+D diet showed highest hatching rate among the groups, followed by FD, FA, NF, and the lowest was FCon group (Table 5). Broodstock fed FA attained the highest fecundity and it was comparable to FA+D group. Broodstock fed NF showed lower fecundity than FA and FA+D treatments but higher than FCon group. Broodstock given $\mathrm{FA}+\mathrm{D}$ diet managed to produce greatest number of larvae and showed significantly higher $(\mathrm{P}<0.05)$ zoea II survival rate than NF and FCon groups, but not significantly different $(\mathrm{P}>$ $0.05)$ from FA and FD groups. There was no significant difference $(P>0.05)$ in the zoea survival rate in broodstock provided NF and FCon diets. 


\section{Discussion}

Results of the present study indicating the role of FA+D diet in boosting sexual maturation and spawning in the mangrove crab, exceeding the performance of FCon diet, are consistent with the findings on black tiger prawn, $P$. monodon (Huang et al., 2008). In the prawn, the maturation diet supplemented with HUFA $10 \mathrm{~g} \mathrm{~kg}^{-1}$ (= DHA $45.9 \%$ of total fatty acids in the diet) and astaxanthin $50 \mathrm{mg} \mathrm{kg}^{-1}$, positively influenced the fecundity and spawning rate. Data on the nutritional performance of these diets that indicated a higher efficiency of FA+D and FD in producing gonadal maturation and spawning success than NF treatment are comparable to the results obtained on the broodstock of green mangrove crab (S. paramamosain) where DHA $10.6 \mathrm{~g}$ $\mathrm{kg}^{-1}$ supplemented in the maturation diet, resulted in almost similar maturation and spawning rate than control group fed natural food comprising shrimp, squid and forage fish (Djunaidah et al., 2003). Apparently, DHA that plays a pivotal role in fertility is mobilized from hepatopancreas to ovary for oogenesis and vitellogenesis (Tantikitti et al., 2015). It is also associated with the carotenoid accumulation in ovarian tissue to protect the lipid fractions from peroxidation damage (Tantikitti et al., 2015). Observations made by Paibulkichakul et al. (2008) also documented that DHA concentration in the ovarian tissue of broodstock increased when fed astaxanthin at the rate of $500 \mathrm{mg} \mathrm{kg}^{-1}$ compared to the test specimens which received less astaxanthin $(100 \mathrm{mg}$ $\mathrm{kg}^{-1}$ ). This study also pointed to the role of astaxanthin as a potential inhibitor of peroxidation of DHA.

Data generated by these trials demonstrating lack of any significant difference in the performance of FA+D, FD and FA diets as far as the values of GSI and oocytes diameter are concerned lend support to the observations made earlier by Wu et al. (2007) on broodstock of Chinese mitten crab. The same holds good for the other set of observations pertaining to FCon and NF treatments. Chinese mitten crab fed with diet supplemented with HUFA ( $\left.25 \mathrm{~g} \mathrm{~kg}^{-1}\right)$ containing DHA amounting to $13.0 \%$ of total fatty acids in the diet resulted in significantly higher GSI than broodstock fed control diet with HUFA $3 \mathrm{~g} \mathrm{~kg}^{-1}$ and DHA $1.45 \%$ of total fatty acids. Concordant views have been expressed by Pangantihon-Kuhlmann et al. (1998) who noticed that supplementing the tiger prawn broodstock diet with astaxanthin at the rate of $100 \mathrm{mg} \mathrm{kg}^{-1}$ significantly increased the GSI. Sagi et al. (1996) reported similar findings on the broodstock of crayfish (Cherax quadricarinatus). Investigations carried out on fish further substantiate the results obtained on marine invertebrates. Thus, the astaxanthin supplementation of $150 \mathrm{mg} \mathrm{kg}^{-1}$ in the maturation diet of gold fish broodstock (Carassius auratus) led to the formation of oocytes of greater diameter than those fed control diet without astaxanthin $(\mathrm{P}<0.05)$ (Tizkar et al., 2013).

The foregoing discussion provides an overwhelming scientific evidence showing a strong correlation between the diameter of oocytes and concentration of astaxanthin. This suggests the association of astaxanthin with vitellin and vitellogenin during ovarian development. It is mainly the accumulation of yolk that determines the egg size (Beacham et al., 1990). The author also described the direct link between heavier and larger eggs with the size of hatchlings. Obviously, larger eggs with more nutritional content are in a better position to support embryonic development leading to the formation of larvae (Tizkar et al., 2013).

In the present study, broodstock fed FA+D diet showed significantly better molting rate and lower MDS than $\mathrm{NF}$ and FCon groups $(\mathrm{P}<0.05)$. This finding was supported by Xu et al. (1993), where Chinese prawn (P. chinensis) fed with diet containing DHA $10 \mathrm{~g}$ kg-1 showed higher molting frequency than control diet without DHA $(\mathrm{P}<0.01)$. This enabled the authors to link HUFA such as DHA with the biosynthesis of hormone-like substances called as eicosanoids that play a crucial role in the crustacean molting. Results are not different in other investigations, one of which involved supplementing astaxanthin $\left(60 \mathrm{mg} \mathrm{kg}^{-1}\right)$ in the diet of kuruma prawn (P. japonicus) that achieved successful molting and faster growth than the batch of the prawn fed diet without astaxanthin (Petit et al., 1997). These authors provided a more elaborate interpretation of the physiological mechanisms that point towards the metabolic interaction of astaxanthin. This, in turn, increases the output of ecdysteroid hormone to suppress molting inhibitory substances, resulting in shortening of the intermolt period that allows increase in molting frequency (Petit et al., 1997). Analysis of the data obtained in this study and synthesis of information that relevant investigations have generated emphasized the need for supplementing the crab diet with both astaxanthin and DHA for promoting successful molting and diminishing the MDS in the broodstock.

It is evident from the findings of this study that there was no significant difference $(P>0.05)$ in the survival rate of broodstock fed diets FA+D, FD, FA and NF but the performance of FCon group was significantly lower $(\mathrm{P}<$ 0.05). Huang et al. (2008) also did not notice any appreciable effect on broodstock survival when diets provided were supplemented with HUFA (10 $\mathrm{g} \mathrm{kg}^{-1}$ ) and astaxanthin (50 mg $\mathrm{kg}^{-1}$ ) compared to the specimens fed natural food. However, Pan et al. (2004) working on tiger prawn found that supplementation of astaxanthin amounting to $240 \mathrm{mg} \mathrm{kg}^{-1}$ significantly enhanced the survival rate compared to the control set maintained without astaxanthin.

The present study conclusively shows improved broodstock survival by diets supplemented with both DHA and astaxanthin but also points to the other factors, particularly the cannibalism and MDS, that matter in the percentage of survival. In fact, losses on account of cannibalism should be considered as a major challenge to profitability and sustainability of the mangrove crab aquaculture industry (Shelley et al., 2011; Romano et al., 2017). Providing crab shelters in the culture tanks and isolating the newly molted crab into net basket for their safety reduced cannibalism but not completely eliminated this problem in the tank culture. 
Higher hatching rate and zoea survival were also seen in crab provided FA+D, FD and FA diets compared to those maintained on NF and FCon diets. Djunaidah et al. (2003) working on green mangrove crab also obtained similar results when the diet was supplemented with DHA at the rate of $10.6 \mathrm{~g} \mathrm{~kg}^{-1}$. Likewise, supplementing the diet with astaxanthin $100 \mathrm{mg} \mathrm{kg}^{-1}$ contributed to significantly higher $(\mathrm{P}<0.05)$ hatching rate in tiger prawn (PangantihonKuhlmann et al., 1998). Xu et al. (1994) established the link between the dietary DHA and hatching rate, and attributed it to the influence of these substances on early embryogenesis. Regarding the positive effect of FA+D and FA on fecundity and total number larvae produced vis-à-vis NF and FCon treatments, it is evident that these nutrients provide precursors that are essential for oogenesis and quality of intraovarian oocytes. Data published by Djunaidah et al. (2003) lends support to the present observations. Likewise, the supporting role of astaxanthin in development of fecundity and egg quality as documented by Huang et al. (2008) is evident from data generated by this investigation.

\section{Conclusion}

The present study established that the captive broodstock of mangrove crab requires supplemented diet for maturation, egg quality and fertility. Adequate nourishment using diets supplemented with ingredients of proven physiological value is vitally important not only in maturation of broodstock, egg quality and hatching rate but also survival, molting and growth of the juveniles. In this context, astaxanthin and DHA are the substances of crucial significance in broodstock nourishment. Aquaculture nutrition is a key area of aquaculture research and development. Further studies might lead to more exciting results with a potential of greatly contributing to sustainability of aquaculture.

\section{Acknowledgements}

The present study was partially funded by the Ministry of Education of Malaysia under the Higher Institutions' Center of Excellence program at Borneo Marine Research Institute (grant HiCOE-0001). The authors acknowledge with gratitude the help of Bizen Co-Ltd (Japan) for supply of the DHA tuna oil (80\% purity) and DSM (Switzerland) for sharing information on synthetic astaxanthin (10\% purity).

\section{References}

Alava, V. R., Kanazawa, A. \& Teshima, S. (1993). Effect of dietary phospholipids and n-3 highly unsaturated fatty acids on ovarian development of kuruma prawn. Nippon Suisan Gakkaishi 59, 345-351.

Alava, V. R., Quinitio, E. T., B de Pedro, Jennete. et al. (2007). Lipids and fatty acids in wild and pond-reared mud crab Scylla serrata (Forsskal) during ovarian maturation and spawning. Aquaculture Research 38, 1468-1477.

Beacham, Terry D. \& Murray, Clyde B. (1990). Temperature, egg size, and development of embryos and alevins of five species of Pacific salmon: a comparative analysis. Transactions of the American Fisheries Society 19, 927-945.
Cavalli, R. O., Lavens, P. \& Sorgeloos, P. (1999). Performance of Macrobrachium rosenbergii broodstock fed diets with different fatty acid composition. Aquaculture 179, 387-402.

Dall, W., Smith, D. M. \& Moore, L. E. (1995). Carotenoids in the tiger prawn Penaeus esculentus during ovarian maturation. Marine Biology 123, 435-441.

Djunaidah, I. S., Wille, M., Kontara, E. K. et al. (2003). Reproductive performance and offspring quality in mud crab (Scylla paramamosain) broodstock fed different diets. Aquaculture International 11, 3-15.

Felix-Valenzuela, L., Higuera-Ciaparai, I. \& Goycoolea-Valencia, F. (2000). Supercritical cojethanol extraction of astaxanthin from blue crab (Callinectes sapidus) shell waste. Journal of Food Process Engineering 24, 101-112.

Guillou, A., Choubert, G., Storebakken, T. et al. (1989). Bioconversion pathway of astaxanthin into retinol in mature rainbow trout (Salmo gairdneri). Comp. Biochem. Physiol 94B, 481-485.

Helrich, K. (1990). Official method of analysis of the association of official analytical chemists. Association of Official Analytical Chemists Inc, 771 pp. USA

Huang, J. H., Jiang, S. G., Lin, H. Z. et al. (2008). Effects of dietary highly unsaturated fatty acids and astaxanthin on the fecundity and lipid content of pond-reared Penaeus monodon (Fabricius) broodstock. Aquaculture Research 39, 240-251.

Islam, M. S., Kodama, K. \& Kurokura, H. (2010). Ovarian Development of the Mud Crab Scylla paramamosain in a Tropical Mangrove Swamps, Thailand. J. Sci. Res. 2, 380-389.

Miki, W. (1991). Biological functions and activities of animal carotenoids. Pure \& App Chem 63, 141-146.

Millamena, Oseni M. (1989). Effect of fatty acid composition of broodstock diet on tissue fatty acid patterns and egg fertilization and hatching in pond reared Penaeus monodon. Asian Fisheries Science 2,127134.

Millamena, Oseni M. \& Quinitio, Emilia T. (1997). Reproductive Performance of Pond-sourced Scylla serrata Fed Various Broodstock Diets. ACIAR Proceeding No. 78 114-117.

Millamena, O. M. \& Quinitio, Emilia T. (2000). The effects of diets on the reproductive performance of eyestalk ablated and intact mud crab Scylla serrata. Aquaculture 181:81-90.

Mohd Sharif, N. A., Shaiful Kahar, N. A. \& Rodrigues, K. et al. (2016). Genetic diversity of mud crabs, Scylla tranquebarica in Sabah, Malaysia based on Cytochrome C Oxidase (COI) gene sequence. Songklanakarin J. Sci. Technol 38, 365-372.

Okada, H., Nur-E-Borhan, S. A. \& Yamaguchi, K. (1994). Carotenoid Composition in the Exoskeleton of Commercial Black Tiger Prawns. Fisheries Science 60, 213-215.

Oniam, V., Chuchit, L. \& Arkronrat, W. (2012). Reproductive performance and larval quality of blue swimming crab (Portunus pelagicus) broodstock, fed with different feeds. Songklanakarin J. Sci. Technol 34, 381-386.

Paibulkichakul, C., Piyatiratitivorakul, S., Sorgeloos, P. et al. (2008) Improved maturation of pond-reared, black tiger shrimp (Penaeus monodon) using fish oil and astaxanthin feed supplements. Aquaculture 282, 83-89.

Pan, C, H. \& Chien, Y. H. (2004). Effects of dietary astaxanthin on body astaxanthin, growth, and survival of Penaeus monodon postlarvae. J. Fish. Soc. Taiwan, 31, 269-280.

Pangantihon-Kuhlmann, M. P., Millamena, O. \& Chern, Y. (1998). Effect of dietary astaxanthin and vitamin A on the reproductive performance of Penaeus monodon broodstock. Aquat. Living Resour 11, 403-409. 
Petit, H., Ne`gre-Sadargues, G., Castillo, R. et al. (1997). The effects of dietary astaxanthin on growth and moulting cycle of postlarval stages of the prawn, Penaeus japonicus (Crustacea, Decapoda). Comp. Biochem. Physiol 117A, 539-544.

Quinitio, E.T., Parado-Estepa, F. D., Millamena. et al. (2001). Seed production of mud crab Scylla serrata juveniles. Asian Fisheries Science $14,161-174$

Quinitio, E.T., Pedro, J. \& Parado-Estepa, F. D. (2007). Ovarian maturation stages of the mud crab Scylla serrata. Aquaculture Research $38,1434-1441$.

Romano, N. \& Zeng, Chaoshu. (2017). Cannibalism of decapod crustaceans and implications for their aquaculture: A review of its prevalence, influencing factors, and mitigating methods. Fisheries Science and Aquaculture 25, 42-69.

Sachindra, N.M., Bhaskar, N. \& Mahendrakar, N.S. (2005). Carotenoids in crabs from marine and fresh waters of India. LWT 38, 221-225.

Sagi, A., Shoukrun, R., Khalaila, I. et al. (1996). Gonad maturation, morphological and physiological changes during the first reproductive cycle of the crayfish Cherax quadricarinatus female. Invertebrate Reproduction and Development 29, 235-242.

Sawanboonchun, J., Roy, W. J., Robertson, D. A. et al. (2008). The impact of dietary supplementation with astaxanthin on egg quality in Atlantic cod broodstock (Gadus morhua, L.). Aquaculture 283, 97-101.

Shelley, C. \& Lovatelli, A. (2011). Mud crab aquaculture A practical manual. FAO Fisheries and Aquaculture Department, 78 pp. Rome, Italy

Sui, L. Y., Sun, H. X., Wu, X. G. et al. (2011). Effect of dietary HUFA on tissue fatty acid composition and reproductive performance of Chinese mitten crab Eriocheir sinensis (H. Milne-Edwards) broodstock. Aquacult Int 19, 269-282.

Tanaka, Y., Matsuguchi, H., Katayama, T. et al. (1976). The biosynthesis of astaxanthin XVI the carotenoid in crustacea. Comp. Biochenl Physiol 54B, 391-393.

Tantikitti, C., Kaonoona, R. \& Pongmaneerat, J. (2015). Fatty acid profiles and carotenoids accumulation in hepatopancreas and ovary of wild female mud crab (Scylla paramamosain, Estampador, 1949). Songklanakarin J. Sci. Technol 37, 609-616.

Tizkar, B., Soudagar, M., Bahmani, M. et al. (2013). The effects of dietary supplementation of astaxanthin and B-caroten on the reproductive performance and egg quality of female goldfish (Carassius auratus). Caspian J. Env. Sci 11, 217-231.

Tizkar, B., Soudagar, M., Bahmani, M. et al. (2016). Effects of dietary astaxanthin and $\beta$-carotene on gonadosomatic and hepatosomatic indices, gonad and liver composition in goldfish Carassius auratus (Linnaeus, 1758) broodstocks. Lat. Am. J. Aquat. Res 44, 363-370.

Verakunpiriya, V., Mushiake, K., Kawano, K. et al. (1997). Supplemental effect of astaxanthin in broodstock diets on the quality of yellowtail eggs. Fisheries Science 63, 816-823.

Watanabe, T., Itoh, A., Murakami, A. et al. (1984). Effect of nutritional quality of diets given to broodstock on the verge of spawning on reproduction of red sea bream. Bulletin of the Japanese Society of Scientific Fisheries 50, 1023-1028.

Wen, X. B., Chen, L., Zhou, Z. L. et al. (2002). Reproduction response of Chinese mitten-handed crab (Eriocheir sinensis) fed different sources of dietary lipid. Comparative Biochemistry and Physiology 131, 675-681.

Wu, X., Cheng, Y., Sui, L. et al. (2007). Effect of dietary supplementation of phospholipids and highly unsaturated fatty acids on reproductive performance and offspring quality of Chinese mitten crab, Eriocheir sinensis (H. Milne-Edwards), female broodstock. Aquaculture 273, 602-613.

Xu, X., Ji, W., Castell, J. et al. (1993). The nutritional value of dietary n-3 and 12-6 fatty acids for the Chinese prawn (Penaeus chinensis). Aquaculture 118, 277-285.
Xu, X., Ji, W., Castell, J. et al. (1994). Influence of dietary lipid sources on fecundity, egg hatchability and fatty acid composition of Chinese prawn (Penaeus chinensis) broodstock. Aquaculture 119, 359-370. 